\title{
Milli-International Unit per Milliliter per Meter Squared
}

National Cancer Institute

\section{Source}

National Cancer Institute. Milli-International Unit per Milliliter per Meter Squared. NCI

Thesaurus. Code C119409.

A unit of concentration (biologic activity) equal to one milli-international unit per milliliter, divided by meters squared. 